\title{
Recombinant polypeptides for serology of malaria
}

Indresh K. Srivastava ${ }^{1}$, Bela Takacs ${ }^{2}$, Patrick Caspers ${ }^{2}$, U. Certa ${ }^{2}$, I. A. McGregor ${ }^{3}$, J. Scaife ${ }^{4}$ and Luc H. Perrin ${ }^{1}{ }^{1}$ Blood Transfusion Centre, Hôpital Cantonal, 1211 Geneva 4, Switzerland; ' ${ }^{2}$ Central Research Unit, Hoffman-La-Roche and Co. Ltd, 4002 Basel, Switzerland; ${ }^{3}$ Department of Tropical Medicine, Liverpool School of Tropical Medicine, Liverpool, UK; ${ }^{4}$ Department of Molecular Biology, King's Building, University of Edinburgh, EH9 $3 F R$, UK

\begin{abstract}
We have evaluated 3 molecularly defined polypeptides encoded by encloned Plasmodium falciparum genes for their ability to serve as antigens for detecting antimalaria antibodies. The recombinant proteins correspond to (i) a conserved part of 190 $200 \mathrm{kDa}$ schizont merozoite surface component, (ii) the carboxy terminal part of the $P$. falciparum aldolase, and (iii) the $5 \cdot 1$ antigen. Antibodies were detected using enzyme-linked immunosorbent assays (ELISA) in a high percentage of sera from individuals from a malaria endemic area in The Gambia (up to $99 \%$ for some adult groups). These results were further improved, especially for detection of antimalaria antibodies in children, when a pool of all 3 polypeptides (ELISA MIXT) was used as antigen. This ELISA MIXT improves presently available assays for the detection of antimalaria antibodies directed against asexual blood stages in respect of standardization, sensitivity and specificity.
\end{abstract}

\section{Introduction}

Qualitative and quantitative determination of specific antibodies is important for measuring the impact of malaria eradication or control programmes at the population level, in malaria endemic areas. In the future antimalarial antibodies in defined areas should be monitored before, during and after vaccination trials. In developed countries, measurement of malaria antibodies can be employed to screen sera of blood donors returning from areas where malaria is endemic.

Several methods are available for the detection of antimalarial antibodies directed against asexual blood stages. Earlier tests relied on gel diffusion or on passive agglutination of sensitized erythrocytes. Other, more sensitive, tests include the indirect fluorescent antibody assay (IFA), radioimmunoassay (RIA) and enzyme-linked immunosorbent assay (ELISA) (PERRIN et al., 1984). RIA and ELISA are now used increasingly for epidemiological studies because they combine sensitivity, low cost and the possibility of automation.

The major limitation of these assays is the supply of standardized reagents, particularly defined antigens. The common sources of antigens are infected red blood cells (IRBC) collected from either infected human individuals or animals (VOLLER et al., 1974) and more recently asexual blood stages of Plasmodium falciparum produced by culture in vitro (SPENCER $e t$

Corresponding author: Dr Luc H. Perrin, Centre de Transfusion Sanguine, Hôpital Cantonal, Université de Genève, 1211 Genève 4, Switzerland. $a l ., 1979)$. The IRBC extracts contain a wide array of non-parasitic antigens including erythrocyte components and break-down products of the parasite. Consequently, the use of total IRBC extract as antigen in ELISA could result in errors resulting from the high incidence of heterophile antibodies, antiglobulins or autoantibodies (ROSENBERG et al., 1973) in the sera of individuals living in malaria endemic regions.

The genes encoding a number of parasite polypeptides have recently been cloned and expressed in appropriate vectors (KEMP et al., 1986). Some recombinant $P$. falciparum components are now produced in high yield and purity and thus provide a source of molecularly defined polypeptides which can be used for malaria serology.

We used the following $3 P$. falciparum recombinant polypeptides at an identical molar concentration to measure antimalarial antibodies in a human population living in an endemic area, by means of microELISAs.

(i) A conserved region of the main schizontmerozoite surface protein termed 1901. (GENTZ et al., 1988).

(ii) Two-thirds of the $41 \mathrm{kDa}$ protein (parasite aldolase) with a molecular mass of $27 \mathrm{kDa}$ expressed in Escherichia coli (aa 112 to aa 360 ; U. Certa, unpublished results).

(iii) An exported antigen of the erythrocytic stage having one or more cross-reactive epitope(s) in common with the circumsporozoite protein of $P$. falciparum (HOPE et al., 1985; COPPEL et al., 1985), designated the 5:1 antigen.

In this investigation, 3 main points are addressed: (i) the suitability of these recombinant polypeptides for the development of serological tests, (ii) the age-dependent development of antibody to these defined polypeptides and the correlation between antibody levels against the 3 polypeptides, and (iii) the effect of the pooled polypeptides on the sensitivity of the micro-ELISA assay.

\section{Materials and Methods \\ Sera}

Sera samples were collected from 361 inhabitants (children and adults) of Keneba village in The Gambia during a malarial survey and stored frozen at $-20^{\circ} \mathrm{C}$ until used. At the same time of sample collection, thick smears were also prepared for every individual and later examined microscopically for the presence of malaria parasites. All relevant information, including age, sex and previous history, was collected for every individual included in the study.

Serum samples from 5 adults in Cameroon, who had frequent bouts of malaria and an IFA antimalarial 
antibody titre of $1: 6400$ constituted a pool of positive sera. Similarly, a pool of 5 sera collected from individuals never exposed to malaria and negative for antimalarial antibodies by IFA served as a negative control.

Samples collected from 46 normal healthy blood donors without any past history of malaria were also included in the study as controls.

\section{Preparation of antigens for micro-ELISA assay}

Antigen $5 \cdot 1$. Bacterial pellets, containing the recombinant malaria antigen $5 \cdot 1$, were suspended in $25 \mathrm{mM}$ imidazole-HCl buffer, $\mathrm{pH} 7 \cdot 4$, to about $4 \times 10^{10}$ cells $/ \mathrm{ml}$. Deoxyribonuclease (DNase) I was added to $5 \mu \mathrm{g} / \mathrm{ml}$. Protease inhibitors, trasylol and phenylmethylsulphonyl fluoride (PMSF), were added to 100 units $/ \mathrm{ml}$ and $1 \mathrm{mM}$ respectively. Cells were broken in a French pressure cell at $138000 \mathrm{kPa}[20000 \mathrm{lbf} /$ in $^{2}$ ]. Cell lysis, monitored by phase contrast microscopy, was greater than $98 \%$. The crude cell lysate was centrifuged at $42000 \mathrm{rpm}$ for $60 \mathrm{~min}$. More than $90 \%$ of the antigen was recovered in the supernatant as assessed by sodium dodecyl sulphate-polyacrylamide gel electrophoresis (SDS-PAGE; TAKACS, 1979).

Solid urea was added to the supernatant to a final concentration of $6 \mathrm{M}$, and the 5.1 antigen was purified by chromatofocusing on a polybuffer exchanger column (PBE 94, Pharmacia), equilibrated with $25 \mathrm{mM}$ imidazole-HCl buffer, $\mathrm{pH} 7 \cdot 4$, containing $6 \mathrm{M}$ urea. Approximately $100 \mathrm{mg}$ of protein were applied with polybuffer $74-\mathrm{HCl}, \mathrm{pH} \mathrm{4}$, diluted $1: 8$ with water and containing $6 \mathrm{M}$ urea. Antigen purification was monitored by SDS-PAGE. Fractions containing the 5.1 antigen were pooled and precipitated by dialysis against saturated ammonium sulphate at $4^{\circ} \mathrm{C}$. This concentration step removed not only polybuffer (composed of amphoteric species) but also eliminated bacterial pigments which co-migrated with antigen $5 \cdot 1$. The precipitated antigen was pelleted by centrifugation, dissolved in phosphate-buffered saline (PBS) containing $4 \mathrm{M}$ urea, and dialysed against the PBS-urea buffer to remove ammonium sulphate. The purity of the antigen preparation was assessed as $95 \%$ by SDS-PAGE.

Mice immunized with the recombinant protein produced antibodies that reacted with a $22 \mathrm{kDa}$ polypeptide on immunoblots prepared from crude extracts of $P$. falciparum merozoites (data not shown).

Antigen 190 L.E. coli W $3110 \mathrm{R}^{-}$paste, containing the recombinant malaria protein $\mathrm{His}_{6} 190 \mathrm{~L}$, was suspended in $25 \mathrm{mM}$ imidazole-HCl, $\mathrm{pH} 7 \cdot 4$, containing $10 \%$ glycerol and $1 \mathrm{mM} \mathrm{MgSO} 4$. Trasylol (100 units $/ \mathrm{ml})$ and DNase $I(5 \mu \mathrm{g} / \mathrm{ml})$ were added and the cells were broken by French pressure cell treatment at $138000 \mathrm{kPa}$. The homogenate was centrifuged at $8000 \mathrm{rpm}$ for $15 \mathrm{~min}$ to sediment debris and unbroken cells. Solid urea and dithiothreitol (DTT) were added to the supernatant fraction to a final concentration of $6 \mathrm{M}$ and $5 \mathrm{mM}$ respectively. The suspension was stirred magnetically for $30 \mathrm{~min}$ at $4^{\circ} \mathrm{C}$ and centrifuged at $42000 \mathrm{rpm}$ for $60 \mathrm{~min}$ to obtain the urea extract. The urea-soluble proteins were then fractionated by chromatofocusing as described above for the $5 \cdot 1$ antigen purification. Fractions containing the recombinant protein were pooled and dialysed against saturated ammonium sulphate at $4^{\circ}$ for $16 \mathrm{~h}$. For further purification the proteins precipitated by ammonium sulphate were dissolved in, and dialysed

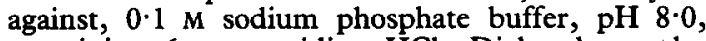
containing $6 \mathrm{M}$ guanidine $\mathrm{HCl}$. Dialysed samples were filtered through a $0.45 \mu \mathrm{m}$ pore size membrane and applied over a $\mathrm{Ni}^{++}$chelate affinity column (GENTZ et al., 1988), equilibrated with $0.1 \mathrm{M}$ sodium phosphate buffer, $\mathrm{pH} 8 \cdot 0$, containing $6 \mathrm{M}$ guanidine $\mathrm{HCl}$. The column was washed with the same buffer with a progressive decrease of $\mathrm{pH}$ from $7 \cdot 0$ to 6.0 , until absorbance at $280 \mathrm{~nm}$ was reduced to background level. The absorbed recombinant peptide was eluted with $0.2 \mathrm{M}$ sodium acetate buffer, $\mathrm{pH} \mathrm{5}$, containing $6 \mathrm{M}$ eq. guanidine $\mathrm{HCl}$. Starting with $6 \mathrm{~g}$ (wet weight) of $E$. coli paste, $16 \mathrm{mg}$ of recombinant protein of more than $95 \%$ purity was obtained.

Antigen C 41. E. coli W $3110 \mathrm{R}^{-}$paste containing the recombinant malarial protein $\mathrm{His}_{6} \mathrm{C} 41$ was treated in the same way as the paste containing $190 \mathrm{~L}$, and $C 41$ was purified to $>98 \%$ purity according to the procedure described above.

\section{Assay procedure}

The micro-ELISA tests were performed as described by GABRA et al. (1986), with slight modifications, in 96-well flat bottomed polystyrene plates (Nunc, Denmark: PS-SH-2-69620). Briefly, the plates were coated with $100 \mu \mathrm{l}$ of antigen diluted in bicarbonate buffer ( $\mathrm{pH} \mathrm{9.6,0.2} \mathrm{M)} \mathrm{supplemented}$ with $1 \mathrm{mg} /$ litre of RIA-grade bovine serum albumin (BSA, Sigma Chemical Co., St Louis, Missouri, USA). The amount of each antigen was adjusted on the basis of the molecular weight of each polypeptide to a concentration of $20 \mathrm{nM}$. After adsorption of the antigens overnight at $4^{\circ} \mathrm{C}$, the plates were washed twice with borate-buffered saline (BBS: $100 \mathrm{mM}$ $\mathrm{H}_{3} \mathrm{BO}_{3}, 30 \mathrm{mM} \mathrm{Na} \mathrm{B}_{4} \mathrm{O}_{7} .10 \mathrm{H}_{2} \mathrm{O}$, and $75 \mathrm{~mm} \mathrm{NaCl}$; pH 8.4) plus $0.4 \%$ Tween-20 (BBST). Non-specific binding sites were then saturated by incubating each well with $150 \mu \mathrm{l}$ of $0.5 \%$ bovine serum albumin (BSA) in BBS for one hour at room temperature. The plates were again washed and $100 \mu \mathrm{l}$ of dilutions of the test sera were added to each well, followed by overnight incubation at $4^{\circ} \mathrm{C}$. Each serum was tested in duplicate at dilutions of $1: 100$ and $1: 2000$ (in $2 \%$ BSA in BBST). After incubation, the plates were washed 6 times with BBST. $100 \mu \mathrm{l}$ of a $1: 300$ dilution of goat anti-human immunoglobulins ( $\lambda$ and $x$ chain specific) coupled with alkaline phosphatase (Cappel Laboratories, Westchester, Pennsylvania, USA) were added to each well and the plates were left for $2 \mathrm{~h}$ at room temperature. After washing the plates, $100 \mu l$ of substrate solution $(1 \mathrm{mg} / \mathrm{ml}$ of $p$-nitrophenylphosphate in $10 \%$ diethanolamine and $0.5 \mathrm{mM} \mathrm{MgCl}$, pH 9.8) were added to each well and the plates were incubated in the dark for $2 \mathrm{~h}$. In order to minimize day-to-day variation in ELISA results, the incubation time was slightly adjusted for each individual plate with respect to positive and negative controls. Positive pooled sera (at dilutions of 1/100,1/400,1/1600 and $1 / 6400)$ and negative pooled sera (1/100 and 1/400) were included on each plate. The ELISA values were measured at $\lambda=405 \mathrm{~nm}$ using a multiscan photometer (Titerskan, Flow Laboratories, Baar, Switzerland). 
Statistical analysis

The results were analysed by computer using the Statistical Package for the Social Sciences (McGraw Hill, New York, NY, USA). Correlation coefficients $(r)$ were calculated using Pearson's test for pairs of variables.

\section{Results}

The age distribution of the Gambian patients in relation to detectable parasitaemia and haemoglobin levels is presented in Table 1 . Most patients in the 0-10 years age group had a patent parasitaemia and relatively low haemoglobin values. With increasing age, the percentage of the population with patent parasitaemia decreased significantly and comparatively higher haemoglobin values were observed.

Micro-ELISA results for Gambian patients and blood donors using the three polypeptides as antigens are summarized in Table 2 . Related to control blood donors, the Gambian patients had very high ELISA values for all 3 antigens. Slightly higher background values were observed using $C 41$ polypeptide compared to the other antigens. The antibody levels

Table 1. Proportion of patients from The Gambia in different age groups with patent parasitaemia and haemoglobin levels

\begin{tabular}{cccc}
\hline $\begin{array}{l}\text { Age group } \\
\text { (years) }\end{array}$ & $\begin{array}{c}\text { No. of } \\
\text { patients }\end{array}$ & $\begin{array}{c}\text { Percentage with } \\
\text { patent parasitaemia }\end{array}$ & $\begin{array}{c}\text { Haemoglobin level } \\
\text { mean } \pm \mathrm{SD}^{4}(\mathrm{~g} / \mathrm{dl})\end{array}$ \\
\hline $0-10$ & 128 & $87 \cdot 4$ & $10 \cdot 76 \pm 1 \cdot 91$ \\
$11-20$ & 70 & $60 \cdot 0$ & $12 \cdot 20 \pm 1 \cdot 37$ \\
$21-30$ & 49 & $32 \cdot 0$ & $12 \cdot 92 \pm 1 \cdot 86$ \\
$31-40$ & 39 & $30 \cdot 0$ & $12 \cdot 95 \pm 2 \cdot 07$ \\
$>41$ & 75 & $17 \cdot 3$ & $12 \cdot 25 \pm 1 \cdot 93$ \\
\hline
\end{tabular}

${ }^{\mathrm{S}} \mathrm{S}=\mathrm{Standard}$ deviation. varied considerably among the Gambian patients as reflected by the high standard deviation observed for the 3 antigens. At the 1:100 dilution, a high proportion of patients $(24.7 \%$ for $190 \mathrm{~L}, 45 \cdot 4 \%$ for $5 \cdot 1$, and $0.6 \%$ for $\mathrm{C} 41$ ) had ELISA values $>1.9$. At a serum dilution of 1:2000, only 3.1 and 8.9 percent of patients had values $>1.9$ for $190 \mathrm{~L}$ and 5.1 respectively, while none of the patients had values $>1.9$ for $\mathrm{C}$ 41 .

In order to interpret results of the ELISA, baseline levels are required. Therefore we selected as cut-off points the mean values measured in the control group of blood donors plus 2 standard deviations (SD) or plus 3 SD and determined for each age group of Gambian patients the percentage of sera with values higher than these cut-off points (Table 3). As expected, the percentage of patients with positive ELISAs for the 3 polypeptides increased with age. Fig. 1 presents the average ELISA values for the various age groups; the age-dependent incrcase in antibody levels for $190 \mathrm{~L}$ and 5.1 antigens is quite obvious, while there is only a slight increase in antibody levels to $C 41$.

Correlation between antibodies directed against the 3 antigens is shown in Table 4. A good correlation was observed between levels of antibodies against 190L and $5 \cdot 1$. In contrast, there was only a marginal correlation between antibody levels against $\mathrm{C} 41$ and $5 \cdot 1$ and no significant correlation between $\mathrm{C} 41$ and $190 \mathrm{~L}$.

We next tried to optimize the assay in order to develop a sensitive assay for antimalarial antibody detection useful in epidemiological studies. The antigen source for this improved assay was a mixture of the 3 recombinant polypeptides. For the ELISAs, the antigen solutions were used at $20 \mathrm{nM}$ which

Table 2. ELISA values (absorbance at $\lambda=405 \mathrm{~nm}$ ) in patients from The Gambia and in controls (blood donors)

\begin{tabular}{|c|c|c|c|c|}
\hline \multirow[b]{2}{*}{ Antigens } & \multicolumn{2}{|c|}{$\begin{array}{l}\text { Patients } \\
\end{array}$} & \multicolumn{2}{|c|}{ Blood donors } \\
\hline & $\operatorname{Mean} \pm \mathrm{SD}^{\mathrm{a}}$ & Range & Mean $\pm S D^{\mathrm{a}}$ & Range \\
\hline $190 \mathrm{~L}$ & $\begin{array}{c}0.97 \pm 0.74 \\
(0.31 \pm 0.46)\end{array}$ & $\begin{array}{c}0.05-2 \cdot 0 \\
(0 \cdot 02-2 \cdot 0)\end{array}$ & $\begin{array}{c}0.051 \pm 0.025 \\
(0.029 \pm 0.023)\end{array}$ & $\begin{array}{c}0.006-0.148 \\
(0-0.066)\end{array}$ \\
\hline$\overline{\mathrm{C} 41}$ & $\begin{array}{c}0.56 \pm 0.36 \\
(0.14 \pm 0.10)\end{array}$ & $\begin{array}{c}0 \cdot 07-2 \cdot 0 \\
(0-1 \cdot 15)\end{array}$ & $\begin{array}{c}0.145 \pm 0.043 \\
(0.075 \pm 0.021)\end{array}$ & $\begin{array}{r}0.072-0.264 \\
(0.031-0.117)\end{array}$ \\
\hline$\overline{5 \cdot 1}$ & $\begin{array}{c}1.38 \pm 0.73 \\
(0.66 \pm 0.689)\end{array}$ & $\begin{array}{c}0 \cdot 04-2 \cdot 0 \\
(0-2 \cdot 0)\end{array}$ & $\begin{array}{c}0.037 \pm 0.015 \\
(0.028 \pm 0.011)\end{array}$ & $\begin{array}{c}0.014-0.097 \\
(0.009-0.068)\end{array}$ \\
\hline
\end{tabular}

${ }^{\mathrm{a}} \mathrm{SD}=$ Standard deviation. First line indicates results with a serum dilution of $1: 100$; second line (in parentheses) indicates results with a serum dilution of $1: 2000$.

Table 3. Proportion of seropositive cases among the Gambian patients of various age groups reacting with three recombinant antigens

\begin{tabular}{|c|c|c|c|c|c|c|c|}
\hline \multirow[b]{2}{*}{$\begin{array}{l}\text { Age group } \\
\text { (years) }\end{array}$} & \multirow[b]{2}{*}{ No. } & \multicolumn{2}{|c|}{$190 \mathrm{~L}$} & \multicolumn{2}{|c|}{ Seropositivity (percent) $)^{a}$} & \multicolumn{2}{|c|}{$5 \cdot 1$} \\
\hline & & Mean $+2 \mathrm{SD}$ & Mean $+3 S D$ & Mean $+2 \mathrm{SD}$ & Mean $+3 \mathrm{SD}$ & Mean $+2 \mathrm{SD}$ & Mean +3 SD \\
\hline $0-10$ & 128 & 93 & $81 \cdot 3$ & $78 \cdot 9$ & $70 \cdot 3$ & $87 \cdot 5$ & $85 \cdot 2$ \\
\hline $11-20$ & 70 & $87 \cdot 1$ & $85 \cdot 7$ & $85 \cdot 7$ & 82.9 & 90 & 90 \\
\hline $21-30$ & 49 & 95.9 & 93.9 & $91 \cdot 8$ & $91 \cdot 8$ & 98 & 98 \\
\hline $31-40$ & 39 & $97 \cdot 4$ & $92 \cdot 3$ & $92 \cdot 3$ & $89 \cdot 7$ & 100 & 100 \\
\hline$>41$ & 75 & $97 \cdot 3$ & $94 \cdot 7$ & $90 \cdot 7$ & $89 \cdot 3$ & 98.7 & 96 \\
\hline
\end{tabular}

a Results based on mean ELISA values obtained in control group plus 2 or 3 standard deviations (SD); serum dilution 1/100. 


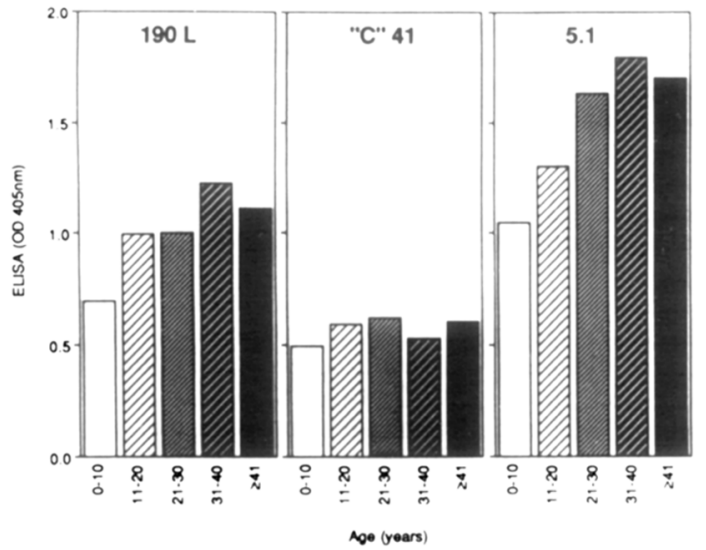

Fig. 1. Mean ELISA values for patients of various age groups using different recombinant polypeptides as antigen.

Table 4. Correlation between ELISA values obtained with different antigens

\begin{tabular}{lll}
\hline \multirow{2}{*}{ Antigens } & \multicolumn{2}{c}{ Antigens } \\
\hline $5 \cdot 1$ & $r=\cdot 521$ & \\
& $P<\cdot 001$ & \\
\hline C 41 & $r=\cdot 148$ & $r=\cdot 385$ \\
& $P<\cdot 05$ & $P<\cdot 001$ \\
\hline
\end{tabular}

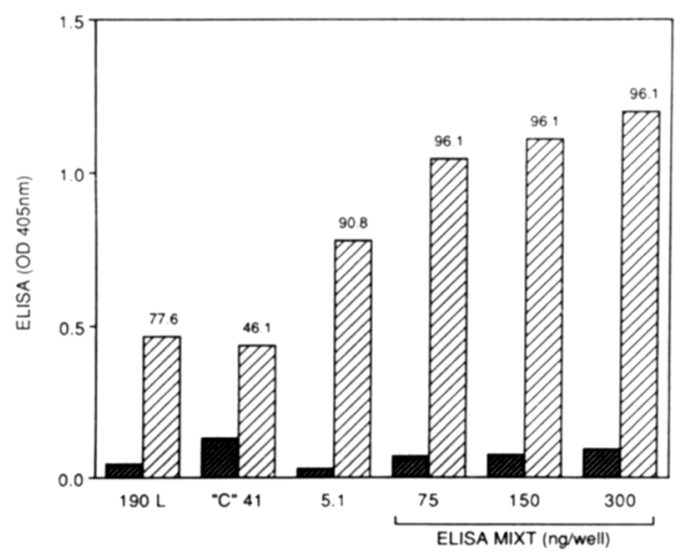

Fig. 2. Comparison of single and pooled antigens in micro-ELISA assay. $\$ Mean ELISA values for patients; 7 control blood donors. Numbers over each column indicate percentage seropositivity at reference value of mean +3 SD (serum dilution $1 / 100$ ).

corresponded to 50,55 and $45 \mathrm{ng} /$ well for $190 \mathrm{~L}, \mathrm{C} 41$ and 5.1 respectively. For the new assay (ELISA MIXT) a mixture containing $40 \mathrm{nM}$ of each antigen was prepared and the wells were coated with dilutions corresponding to $75 \mathrm{ng} / \mathrm{well}, 150 \mathrm{ng} / \mathrm{well}$ and $300 \mathrm{ng} / \mathrm{well}$. To evaluate the sensitivity of the ELISA MIXT, 76 Gambian sera with low ELISA values in one or more of the standard assays (most of them were children) were selected as well as 20 sera from control blood donors. The results of the various assays are shown in Fig. 2. A higher percentage of positive sera was detected by ELISA MIXT than by the standard assays. This was observed when the wells were coated with $75 \mathrm{ng}$ of pooled antigens (in this mixture each single antigen was present at a lower concentration than in the assays based on a single recombinant polypeptide) and with wells coated with higher concentration of antigens. Only 3 sera were negative with the ELISA MIXT using 3 different concentrations of the pooled antigens. These 3 sera, collected from children, were also negative by IFA.

\section{Discussion}

There is a need for improved and cheap immunodiagnostic tests for the qualitative and quantitative measurement of antimalarial antibodies. The routine use of such tests requires a constant and standardized supply of malaria antigens. Conventional sources such as infected red blood cells do not meet these requirements (GABRA et al., 1986; DEMEDTS et al., 1987). Several genes coding for $P$. falciparum and $P$. vivax have been cloned and expressed in appropriate vectors. The sequences of the corresponding polypeptides have been determined and it has been shown that antibodies from individual patients with past malarial infection bind to some of these recombinant polypeptides (BIANCO et al., 1988). No systematic serodiagnostic study has been performed with cloned antigens with the exception of that by GABRA et al. (1986).

We have investigated the suitability of 3 recombinant polypeptides as molecularly-defined malaria antigens for immunodiagnosis. These recombinant antigens were selected on the basis of (i) their known reactivity with antibodies from humans with past malarial infection, (ii) the fact that their amino acid sequences showed little or no variation between different isolates of $P$. falciparum (GENTZ et al., 1988; CERTA et al., 1988), and (iii) a high level of expression in their vectors.

All the polypeptides were suitable for the detection of antimalarial antibodies. A very low background was observed using sera of individuals never exposed to malaria and positive reactivity was detected in almost all the sera of adults of a hyperendemic area (up to $100 \%$ positive sera in some groups of adults for the $5 \cdot 1$ antigen). Antibodies were also reliably detected in most of the sera of children. However, there was a clear difference in the amount of antibody reaction against the three recombinant polypeptides.

Thus, levels of antibodies directed against 5.1 were the highest, followed by antibodies against $190 \mathrm{~L}$ and $C 41$. This was probably not a consequence of passive absorption of antibodies in vivo during an acute attack of malaria, since differences in titre were observed for both the groups with a high incidence of patent parasitaemia (children) and a low incidence (adults). This may however be the reflection of better refolding of 5.1 and $190 \mathrm{~L}$ and $\mathrm{C} 41$, or of the presence of more epitopes able to raise an antibody response on $5 \cdot 1$ and 190 L.

A clear correlation was observed between antibody levels directed against $5 \cdot 1$ and $190 \mathrm{~L}$ but not between antibodies directed against these 2 polypeptides and $C$ 41. This may have been due to very high levels of 
antibody directed against $5 \cdot 1$ and $190 \mathrm{~L}$. When a mixture of the 3 antigens was used, the percentage of positive sera increased significantly with a selection of sera poorly reactive with the individual assays. The 3 sera negative with the ELISA MIXT were also negative in the 3 assays using individual components and in IFA tests. In addition, the level of antibodies (measured by ELISA) was higher and the difference between negative and positive sera was greater.

These results suggest that an ELISA using the 3 recombinant polypeptides, available in relatively high amounts, would be useful for epidemiological studies and would also have the advantage of genuine standardization (use of molecularly defined antigens).

Additional studies are required to determine the ability of this assay to detect cross-reactive antibodies to $P$. vivax epitopes, and to compare the assay directly with IFA; however, published data concerning anti-asexual blood-stage antibody detection in children (MCGREGOR 1974; VOLLER et al., 1980; GABRA et al., 1986) seem to indicate that the ELISA MIXT has a higher sensitivity.

\section{Acknowledgements}

We thank Mrs Kim Zollinger for her expert technical assitance and Mrs C. Brown for preparing the manuscript. This work was supported by the UNDP/World Bank/World Health Organization Special Programme for Research and Training in Tropical Diseases ID no. 870104 and by the Swiss National Research Foundation Grant 3.923.0.87.

\section{References}

Bianco, A. E., Crewther, P. E., Coppel, R. L., Stahl, H. D., Kemp, D. J., Anders, R. F. \& Brown, G. V. (1988). Patterns of antigen expression in asexual blood stages and gametocytes of Plasmodium falciparum. American foumal of Tropical Medicine and Hygiene, 38, 258-267.

Certa, U., Ghersa, P., Döbeli, H., Matile, H., Kocher, H. Srivastava, I. K., Shaw, A. R. \& Perrin, L. H. (1988). Aldolase activity of Plasmodium falciparum protein with protective properties. Science, 240, 1036-1038.

Coppel, R. L., Favaloro, J. M., Crewther, P. E., Burkot, T. R., Bianco, A. E., Stahl, H. D., Kemp, D. J., Anders, R. F. \& Brown, G. V. (1985). A blood stage antigen of Plasmodium falciparum shares determinants with the sporozoite coat protein. Proceedings of the National Academy of Science, USA, 82, 5121-5125.

Demedts, P., Vermeulen-Van Overmeir, C. \& Wéry, M. (1987). Simultaneous use of Plasmodium falciparum crude antigen and red blood cell control antigen in the enzyme-linked immunosorbent assay for malaria. American foumal of Tropical Medicine and Hygiene, 36, 257-263.

Gabra, M. S., Grossiord, D., Perrin, L. H., Shaw, A. R., Cheung, A. \& McGregor, I. A. (1986). Defined Plasmodium falciparum antigens in malaria serology. Bulletin of the World Health Organization, 64, 889-896.

Gentz, R., Certa, U., Takacs, B., Matile, H., Döbeli, H., Pink, R., Mackay, M., Boné, N. \& Scaife, J. (1988). Major surface antigen p190 of Plasmodium falciparum: detection of common epitopes present in a variety of plasmodia isolates. EMBO foumal, 7, 225-230.

Hope, I. A., Mackay, M., Hyde, J. E. \& Scaife, J. (1985). The gene for an exported antigen of the malaria parasite Plasmodium falciparum cloned and expressed in $E$. coli. Nucleic Acid Research, 13, 369-379.

Kemp, D. J., Coppel, R. L., Stahl, H. D., Bianco, A. E., Corcoran, L. M., McIntyre, P., Langford, C. J., Favaloro, J. M., Crewther, P. E., Brown, G. V., Mitchell, G. F., Culvenor, J. G. \& Anders, R. F. (1986). Genes for antigens of Plasmodium falciparum. Parasitology, 91, S83-S108.

McGregor, I. A. (1974). Mechanism of acquired immunity with epidemiological patterns of antibody responses in malaria in man. Bulletin of the World Health Organizatiom, 50, 259-266.

Perrin, L. H., Parez, A. \& Chizzolini, C. (1984). Malaria immunity, vaccination and immunodiagnosis. Experientia, 40, 1343-1350.

Rosenberg, E. B., Strickland, G. T., Yang, S. L. \& Wahlen, G. E. (1973). IgM antibodies to red cells and autoimmune anemia in patients with malaria. American foumal of Tropical Medicine and Hygiene, 22, 146-151.

Spencer, H. C., Collins, W. E., Chin, W. \& Skinner, J. C. (1979). The enzyme-linked immunosorbent assay for malaria I. The use of in vitro cultured Plasmodium falciparum as antigen. American foumal of Tropical Medicine and Hygiene, 28, 927-932.

Takacs, B. (1979). Electrophoresis of proteins in polyacrylamide slab gels. Immunological Methods, 2, 81-105.

Voller, A., Bidwell, D. E., Huldt, G. \& Engvall, E. (1974). A microplate method of enzyme-linked immunosorbent assay and its application to malaria. Bulletin of the World Health Organization, S1, 209-211.

Voller, A., Cornille Brogger, R., Storey, J. \& Molineaux, L. (1980). A longitudinal study of Plasmodium falciparum malaria in West African savanna using the ELISA technique. Bulletin of the World Health Organization, 58, $429-438$.

Received 18 October 1988; revised 24 November 1988; accepted for publication I December 1988 